University of Nebraska - Lincoln

DigitalCommons@University of Nebraska - Lincoln

\title{
Evaluation of Beef Cattle Operations Utilizing Different Seasons of Calving, Weaning Strategies, Postweaning Management, and Retained Ownership
}

\author{
R. E. Kruse \\ Montana State University \\ M. W. Tess \\ Montana State University \\ E. E. Grings \\ USDA-ARS \\ R. E. Short \\ USDA-ARS \\ R. K. Heitschmidt \\ USDA-ARS \\ See next page for additional authors \\ Follow this and additional works at: https://digitalcommons.unl.edu/usdaarsfacpub \\ Part of the Agricultural Science Commons
}

Kruse, R. E.; Tess, M. W.; Grings, E. E.; Short, R. E.; Heitschmidt, R. K.; Phillips, W. A.; and Mayeux, H. S., "Evaluation of Beef Cattle Operations Utilizing Different Seasons of Calving, Weaning Strategies, Postweaning Management, and Retained Ownership" (2008). Publications from USDA-ARS / UNL Faculty. 853.

https://digitalcommons.unl.edu/usdaarsfacpub/853

This Article is brought to you for free and open access by the U.S. Department of Agriculture: Agricultural Research Service, Lincoln, Nebraska at DigitalCommons@University of Nebraska - Lincoln. It has been accepted for inclusion in Publications from USDA-ARS / UNL Faculty by an authorized administrator of DigitalCommons@University of Nebraska - Lincoln. 


\section{Authors}

R. E. Kruse, M. W. Tess, E. E. Grings, R. E. Short, R. K. Heitschmidt, W. A. Phillips, and H. S. Mayeux 


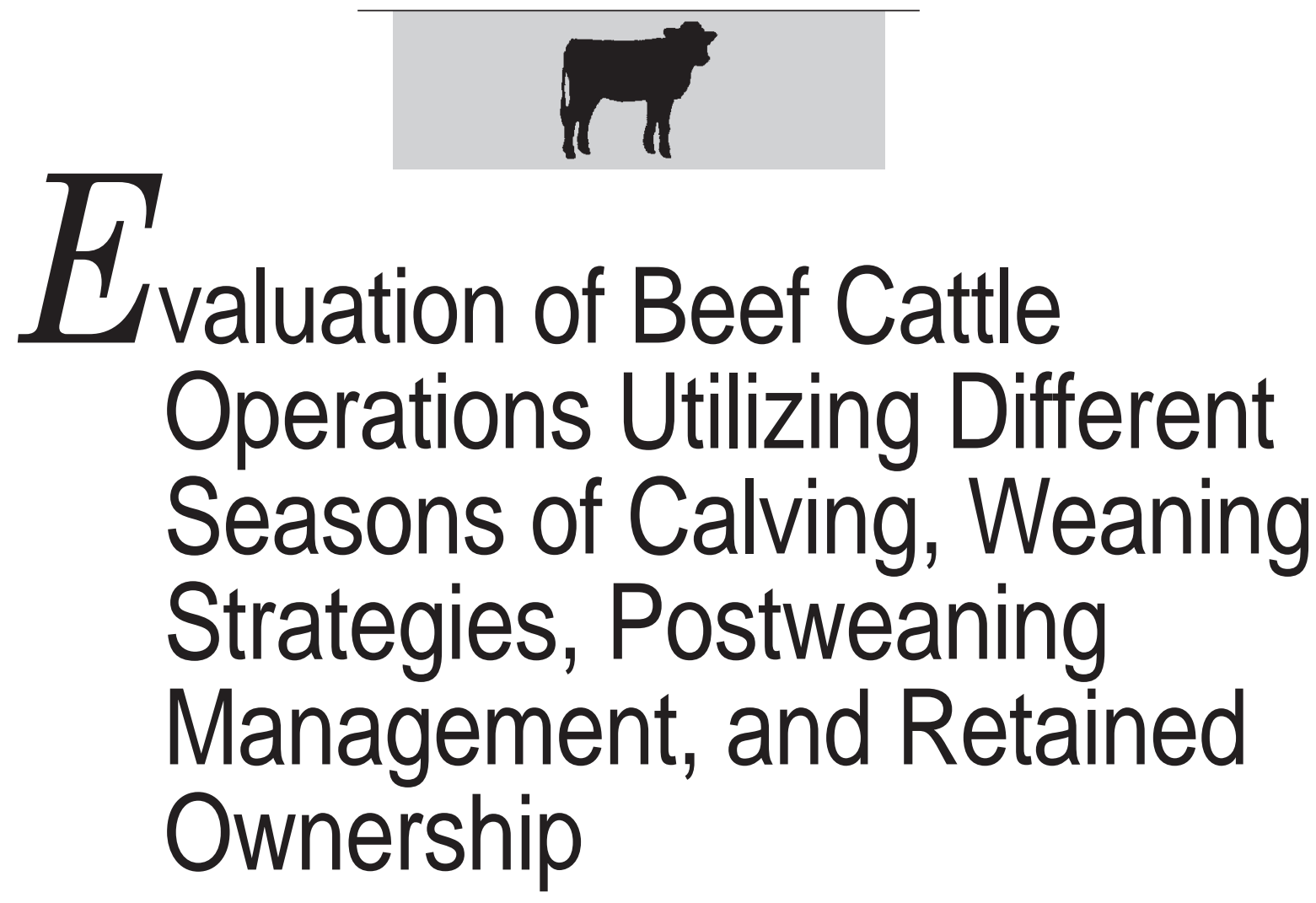

\begin{abstract}
R. E. Kruse, ${ }^{*}$ M. W. Tess, ${ }^{* 1}$ PAS, E. E. Grings, $†$ R. E. Short, $\uparrow$ R. K. Heitschmidt, $†$
W. A. Phillips, $¥$ PAS, and H. S. Mayeux

*Department of Animal and Range Sciences, Montana State University, Bozeman 59717; †USDAARS, Fort Koegh Livestock and Range Research Laboratory, Miles City, MT 59301; and fUSDAARS, El Reno, OK 73036
\end{abstract}

\begin{abstract}
Data from a 3-yr study in Montana were utilized to evaluate impacts of season of calving, weaning strategy, and retained ownership of steer calves on enterprise profitability. Calving seasons were late winter (LW), early spring (ES), or late spring (LS). Each season had 2 weaning times: 190 (LW190, ES190) or 240 (LW240, ES240) d for $L W$ and $E S$, and 140 (LS140) or 190 (LS190) d for LS. Backgrounding options included shipping steers to Oklahoma (OK1), or backgrounding in Montana to a constant age (MT2) or weight (MT3). Steers from OK1 and MT2 were finished in Oklahoma in confinement or via self-feeders on pasture and harvested in Texas. Steers in MT3 were finished in Montana in confinement and
\end{abstract}

${ }^{1}$ Corresponding author: mwtess@montana. edu harvested in Colorado. Performance of each system was modeled based on actual animal performance, market prices, and variable input costs. When calves were sold at weaning, gross margins per cow were greatest for LS190 (P $<0.05)$ and lowest for LW240. During backgrounding, costs of gain were similar among cow-calf systems, and gross margins per steer were greatest for LS140 ( $P<0.05)$, but not different among backgrounding systems. During finishing, costs of gain were greatest for steers from MT2 due to transportation costs to Oklahoma $(P<0.05)$, and gross margin per steer favored MT3 ( $P$ $<0.05)$. Gross margin for a ranch with a fixed land base did not differ among systems if calves were sold at weaning, but was greatest for LS systems after backgrounding or finishing $(P<0.05)$.

Key words: beef cattle, calving date, marketing, system

\section{INTRODUCTION}

Timing of calving can affect the synchrony between the nutrient dynamics in forage and nutrient requirements of beef cows, producing large effects on inputs and outputs from a rangeland-based cow-calf production system (Adams et al., 1996; Stockton et al., 2007). Feed cost is one of the most important variables that influences profit in a production system and has been reported to be approximately $70 \%$ of the total cost of raising beef cows (Peterson et al., 1987). Feed costs are highly related to weaning dates (May et al., 1999b; Reisenauer Leesburg et al., 2007a). Calving earlier in the year may increase weaning weights (Julien and Tess, 2002; Reisenauer Leesburg et al., 2007a). An optimal calving season balances outputs and inputs to maximize profit. Several management and marketing alternatives 
exist for weaned calves. Postweaning management or marketing decisions can greatly affect the ranks of alternative calving seasons for profitability (Reisenauer Leesburg et al., 2007b). Because few large finishing or harvesting facilities are located in the Northern Great Plains, an important part of postweaning management and marketing for ranches in this region includes when and where to finish calves before harvest.

The USDA-ARS conducted a large multi-regional experiment to evaluate the timing of calving in combination with several postweaning management or marketing scenarios (Grings et al., 2005, 2006, 2007; Phillips et al., 2006). The objective of this study was to evaluate the economic performance of production or marketing systems studied in this project. Specifically, our objective was to evaluate late winter, early spring, and late spring calving in Montana in combination with backgrounding and finishing steer calves in Montana or Oklahoma.

\section{MATERIALS AND METHODS}

\section{Overview}

The USDA-ARS multi-regional project was designed to make inferences to practical production practices utilized for calves born in the Northern Great Plains. Cow herds were located at the Fort Keogh Livestock and Range Research Station near Miles City, Montana (LARRL). Crossbred cows of similar genetic composition were managed to calve in 1 of 3 seasons: late winter (LW; average $=$ February 8 , range $=$ January 21 to March 3), early spring (ES; average $=$ April 5 , range $=$ March 15 to May 4), or late spring (LS; average $=$ May 31, range $=$ May 16 to June 26). Calving seasons were the result of 32-d breeding seasons. Each calving season had 2 weaning times: 190 (LW190, ES190) or 240 (LW240, ES240) d of age for LW and ES calves, and 140 (LS140) or 190 (LS190) d for LS calves. Replacement heifers were managed in 1 of 2 development strategies. From weaning to breeding, heifers 1) were fed a diet based on corn silage and hay intended to produce a constant rate of gain (CG), or 2) grazed low-quality forage or were fed hay for a period of time followed by a corn silage-hay diet for the last 3 mo before breeding intended to produce a more delayed gain (DG) growth pattern. Details of the experimental protocols, management, and cattle performance were presented by Grings et al. (2005, 2007).

After weaning steer calves were assigned to 1 of 3 backgrounding systems: 1) winter wheat pasture in Oklahoma (OK1), 2) a corn silagebased grower diet fed in drylot until shipment to Oklahoma (MT2), or 3) a corn silage-based grower diet fed in drylot up to an average weight of $375 \mathrm{~kg}$ (MT3). Steers in OK1 were shipped to Oklahoma in the fall or winter depending on their calving season or weaning age designation. For example, calves from LW were shipped in October and November, whereas calves from LS were shipped as late as early February. Calves grazed winter wheat until the first week of June. Steers in MT2 were shipped to Oklahoma in late May.

Steers backgrounded in OK1 and MT2 were allotted to 1 of 2 finishing systems in Oklahoma in which steers were fed a high-energy diet: 1) in confinement in a traditional feedlot, or 2) via a self-feeder on pasture. All steers in MT3 were finished in confinement on a high-energy diet. Steers in both Oklahoma and Montana were harvested based on visual appraisal of backfat thickness with the goal of $10 \mathrm{~mm}$. Harvest facilities were in Texas for steers finished in Oklahoma (OK1 and MT2), and in Colorado for steers finished in Montana (MT3).

All backgrounding (OK1) and finishing (OK1 and MT2) in Oklahoma was conducted at the Grazinglands Research Laboratory near El Reno, Oklahoma, and all backgrounding and finishing in Montana was conducted at LARRL. Due to drought, steers from ES240 and LS190 born in 2000 and assigned to OK1 were not shipped to Oklahoma and fed according to protocol; hence, data collected from these steers were not used in modeling the backgrounded and finishing segments. Details of the experimental protocols, management, and cattle postweaning performance were presented by Grings et al. (2006) and Phillips et al. (2006).

\section{Modeling Production System Performance}

Our approach was to model the production systems implied by the research design; i.e., feeding and managing cattle as described in the original research. For all aspects of animal performance measured in the studies, annual means were used in the model, thus preserving much of the variation in performance and permitting some statistical evaluation of the results. Gross margin (gross returns minus variable costs) is the measure of economic performance emphasized in this paper. Because a primary variable of interest in the cow-calf segment was supplemental feed costs, we attempted to predict economic performance in basic units: on a ranch basis and on an animal basis. No stochastic elements were included in the model.

Cow-calf Systems. Gross margin per cow highlights costs and returns for the reproductive unit of a beef cattle enterprise (the breeding-age female), but fails to recognize the most fundamental constraint of most range-based operations; i.e., land. In the short-term, most ranchers have very limited opportunity to increase land, which represents the grazeable forage base of a ranch. Annual expenses associated with land ownership (e.g., principle, interest, taxes, and some insurance and maintenance) tend to be fixed and nearly independent of use. Therefore we defined a ranch of a fixed average grazeable forage base and then determined the number of cows that the ranch could sustain under the management system simulated (i.e., calving season, weaning age, 
Table 1. Heifer development purchased feed cost and herd size for combinations of calving season, weaning age, and heifer development ${ }^{1}$

\begin{tabular}{|c|c|c|c|c|c|c|}
\hline Item & LW240 & LW190 & ES240 & ES190 & LS190 & LS140 \\
\hline \multicolumn{7}{|c|}{ Constant gain heifer development (CG) } \\
\hline \multicolumn{7}{|c|}{ Feed cost per heifer, $\$$} \\
\hline 1999 to 2000 & 141 & 176 & 147 & 162 & 127 & 132 \\
\hline 2000 to 2001 & 139 & 178 & 175 & 200 & 141 & 165 \\
\hline 2001 to 2002 & 164 & 200 & 149 & 194 & 133 & 147 \\
\hline Average & 148 & 184 & 157 & 185 & 134 & 148 \\
\hline Herd size, cows & 443 & 537 & 503 & 532 & 471 & 504 \\
\hline \multicolumn{7}{|c|}{ Delayed gain heifer development (DG) } \\
\hline \multicolumn{7}{|c|}{ Feed cost per heifer, $\$$} \\
\hline 1999 to 2000 & 113 & 115 & 127 & 126 & 62 & 54 \\
\hline 2000 to 2001 & 140 & 142 & 158 & 164 & 90 & 99 \\
\hline 2001 to 2002 & 99 & 101 & 122 & 129 & 77 & 65 \\
\hline Average & 117 & 120 & 136 & 139 & 77 & 73 \\
\hline Herd size, cows & 436 & 525 & 502 & 516 & 465 & 482 \\
\hline
\end{tabular}

${ }^{1} \mathrm{LW}=$ late winter, ES = early spring, LS = late spring; 240, 190, $140=$ weaning ages; herd size = number of cows exposed to breeding on ranch of fixed size (4,798 animal unit months).

heifer development). The fixed forage base was 4,798 animal unit months (AUM; $304 \mathrm{~kg} \mathrm{DM/mo;} \mathrm{SRM,} \mathrm{1989)}$ with no hay base; i.e., all hay was assumed to be purchased. Treating hay as a purchased input is computationally equivalent to regarding hay production as a separate enterprise on a ranch.

The original research was designed to allow cows to graze standing forage as much as possible within the constraints of weather and reproductive status. All inputs of supplemental feed were measured (Grings et al., 2005, 2006). Feedstuffs were valued according to regional prices. Table 1 presents means for purchased feed costs for replacement heifers (Grings et al., 2006) averaged over the 3 yr of the study for each combination of calving season, weaning age, and heifer development. Nutritional management of mature cows varied only according to calving season (Grings et al., 2005). Table 2 presents actual purchased feed costs per cow for each year of the study. Note that feed costs varied greatly across years and calving seasons, reflecting the impact of weather and forage availability and the types of feeds used. In the winter of 1999 to 2000, the LS herd required no supplemental feeding (Grings et al., 2005).

Intake of grazed forage was not estimated; however, diet quality of cattle on pasture was estimated (Grings et al., 2005). The Montana State University Beef Simulation Model (Tess and Kolstad, 2000a,b) was used to estimate forage intake of cows, calves, and replacement heifers. Input parameters were designed to mimic the calving season, weaning age, average feed supplementation and reproductive performance (over the $3 \mathrm{yr}$ of the study), the genetic composition of the cow herd, and the diet quality of the forage. Because pregnancy rates were not different among calving seasons (Grings et al., 2005) and because the length of the breeding period was shorter than most commercial ranches (32 d), a culling rate and cow age distribution representative of commercial practice were assumed, with the percentage of the winter inventory in ages $2,3,4,5$, and $6+$ being 14 , $12,11,11$, and $52 \%$, respectively, for all cow-calf systems. The number of replacement heifer calves retained was $111 \%$ of the number of 2 -yr-olds. Table 1 presents the herd sizes as determined by these methods. Comparisons among LW, ES, and LS at a constant weaning age $(190 \mathrm{~d})$ reflect the amount of time cows grazed standing forage versus being fed hay (Grings et al., 2005). Within calv-

\section{Table 2. Purchased feed costs and herd reproductive performance in each calving season}

\begin{tabular}{lccc} 
Item & Late winter & Early spring & Late spring \\
\hline Feed cost per cow, $\$$ & & & \\
1998 to 1999 & 149 & 98 & 88 \\
1999 to 2000 & 76 & 107 & 0 \\
2000 to 2001 & 216 & 279 & 122 \\
Average & 147 & 161 & 70 \\
Calf morbidity, \% & 6 & 2 & 2 \\
Calf mortality, \% & 3.5 & 1.5 & 1.5 \\
Calves weaned per cow calving, \% & 96 & 98 & 98
\end{tabular}


ing seasons, systems that weaned calves at older ages had smaller herd sizes compared with earlier weaning, reflecting the forage intake of calves. This effect increased in magnitude as the calving date moved earlier in the year, reflecting the impacts of lactation and calf age on forage intake. Because the DG heifer development strategy attempted to maximize use of grazed forage, herd size for DG tended to be smaller than for CG across all calving seasons and weaning ages.

All non-feed inputs were valued according to regional prices. Annual expenses incurred on a per animal basis included vaccinations and health treatments, ear tags, synchronization expenses, inventory taxes, opportunity costs of investment (real interest rate, $5 \%$ ), and depreciation ( $\$ 427$, bulls only) and were assumed to be $\$ 11.56, \$ 46.23, \$ 50.57, \$ 51.18$, and $\$ 579.53$ for calves, yearling heifers, 2-yr-olds, mature cows, and bulls, respectively. Small differences in morbidity among calving seasons were computed on a per cow basis using actual drug costs. The cow to bull ratio was 25:1. Variable labor expenses were valued at $\$ 12.50$ / $\mathrm{hr}$, and recorded estimates of hours spent for calving, feeding heifers, and feeding cows were used for each calving season in each year of the study.

In each system, all steer calves and non-replacement heifer calves were assumed to be sold from the ranch at weaning. Culling of yearling replacement heifers and cows occurred at weaning, with all culls marketed at local auction markets $(218 \mathrm{~km}$ distant). All cattle prices were based upon USDA monthly average prices, and steer and heifer calf prices were adjusted for weight according to slides implied from the USDA-quoted prices. Pencil shrink was assumed to be $2 \%$ for calves, and actual shrink on cull females was assumed to be $4 \%$. Commission fees were assumed to be $2.5 \%$, and trucking was charged at $\$ 1.24 /$ loaded $\mathrm{km}$ for $22,380 \mathrm{-kg}$ truck loads. Brand inspection and checkoff fees were $\$ 1.30 /$ head.

\section{Table 3. Average feed costs (\$/steer) for backgrounding and finishing by calving season and weaning age ${ }^{1}$}

\begin{tabular}{|c|c|c|c|c|c|c|}
\hline Item & LW240 & LW190 & ES240 & ES190 & LS190 & LS140 \\
\hline \multicolumn{7}{|c|}{ Backgrounding period } \\
\hline OK1 & 122 & 136 & 86 & 119 & 97 & 117 \\
\hline MT2 & 165 & 190 & 134 & 158 & 121 & 133 \\
\hline MT3 & 133 & 147 & 131 & 146 & 146 & 153 \\
\hline \multicolumn{7}{|l|}{ Finishing period } \\
\hline \multicolumn{7}{|l|}{ OK1 } \\
\hline Confinement & 154 & 149 & 153 & 170 & 168 & 194 \\
\hline Pasture & 182 & 182 & 178 & 182 & 178 & 182 \\
\hline \multicolumn{7}{|l|}{ MT2 } \\
\hline Confinement & 118 & 122 & 134 & 143 & 159 & 148 \\
\hline Pasture & 182 & 182 & 182 & 182 & 182 & 182 \\
\hline \multicolumn{7}{|l|}{ MT3 } \\
\hline Confinement & 93 & 101 & 83 & 68 & 93 & 77 \\
\hline
\end{tabular}

\section{Backgrounding and Finishing} Systems. Feed costs were computed from records of diets fed, including diets used during pre-test periods (e.g., between weaning and shipment for OK1). Feedstuffs were valued using regional prices for the individual years of the project. No feed markup was assumed. Feeding expenses on pasture were computed based on regional averages charges in Oklahoma per kilogram of gain on pasture. Table 3 presents average feed costs for backgrounding and finishing. Differences in feed cost reflect differences among systems in feedstuffs used, time on feed, and weight gained (see Grings et al., 2006; Phillips et al., 2006).

Yardage was charged for all steers backgrounded ( $\$ 0.15 / \mathrm{d})$ or finished (\$0.25/d) in confinement, but not for animals maintained on pasture, reflecting differences in labor and investment and maintenance of facilities. No morbidity or health cost information was collected during the study; therefore it was assumed constant across all systems and not accounted for in the model. A death loss of $1 \%$ was assumed during both backgrounding and finishing. Transportation was computed using the same assumptions as for the cow-calf systems. Distance from Montana to Oklahoma was $1,915 \mathrm{~km}$, from Oklahoma to harvest facilities in Texas was $376 \mathrm{~km}$, and from Montana to harvest facilities in Colorado was 955 $\mathrm{km}$. Interest (i.e., opportunity cost, $5 \%$ ) was charged on transportation to feeding facilities and the initial value of the steers, accounting for the time on feed. Interest on feeding and yardage expenses were computed for half the time on feed because these expenses would be incurred over the span of the feeding period, not just at the beginning.

Backgrounded steers were assumed to be marketed directly from the ranch or lot with a pencil shrink of $2 \%$. Finished steers were sold at the harvest facilities. Steer prices were based upon USDA monthly average prices.

\section{Statistics}

Data were analyzed using the GLM Procedure of SAS (SAS Institute, Cary, NC). Variables analyzed from the cow-calf segment included gross margin per cow and ranch gross margin. The statistical model included cow-calf system (i.e., 6 combinations of calving season and weaning age), heifer development (i.e., DG and 
CG), the interaction between cow-calf system and heifer development, and year.

Because heifer development was not an important source of variation among cow-calf systems (as shown in the Results and Discussion), we chose to consider only the more traditional CG heifer development strategy for comparisons of backgrounding and finishing systems. Variables analyzed for the backgrounding and finishing segments included cost of gain $(\$ / \mathrm{kg})$, gross margin per steer, and cumulative gross margin, which we defined as the added gross margin of feeding the steers from a particular system through one more production segment added to the ranch gross margin from each of the previous segments. The statistical model for the backgrounding phase included cow-calf system, backgrounding system, the interaction between cow-calf system and backgrounding system, and year. The model for the finishing segment included cow-calf system, backgrounding system, finishing system (confinement or pasture), and all interactions involving cow-calf, backgrounding, and finishing systems.

Because the systems were modeled deterministically, all variation within systems was due to differences in animal performance, input prices, and output prices among years. For all analyses, non-significant interactions $(P>0.05)$ were deleted from the models and reduced models were fitted to the data. Multiple comparisons of least squares means were conducted using the Tukey-Kramer method.

\section{RESULTS AND DISCUSSION}

\section{Cow-calf Systems}

Interactions between cow-calf system and heifer development were not significant for gross margin per cow and ranch gross margin; hence only the main effects are presented in Table 4. Differences in gross margin (per cow or per ranch) between heifer development systems were not significant. Although feed costs to develop heifers averaged nearly $\$ 50 /$ yr higher for CG than DG ( $\$ 159$ vs. $\$ 110$, Table 1), they were not large enough to have a significant effect on the cow-calf enterprise as a whole. Pre-breeding weights and reproductive performance for $\mathrm{CG}$ and $\mathrm{DG}$ heifers were not different (Grings et al., 2007).

Gross margin per cow for LS190 was greater than for $\operatorname{ES} 190(P<$ 0.05 ); however, all other comparisons were not significant (Table 4). Differences among cow-calf systems in ranch gross margin were not significant. Ranks of systems were similar based on either measure of gross margin, with LS systems tending to have higher values than either LW or ES $(P>0.05)$. Within calving season systems, weaning calves at older ages tended to be more profitable than those weaning at younger ages $(P>0.05)$.

Grings et al. (2005) reported lighter weaning weights for LS calves than for LW and ES calves. This is similar to the findings of Adams et al. (2001) and Smith et al. (2001) where weaning weight decreased as calving season advanced. Our results show that for cow-calf enterprises selling calves at weaning, LS systems yielded numerically higher ranch gross margin than all other systems, and LS190 was statistically greater than
$\operatorname{ES} 190(P<0.05)$. This is primarily due to higher feed costs for LW and ES (Table 2). This is consistent with the results of May et al. (1999b) and Adams et al. (1994), where later calving reduced feed costs during the winter feeding period. Armstrong et al. (1990) reported that as feed costs increased, net returns decreased regardless of resource constraints, management, or calving rates.

\section{Backgrounding Systems}

For the backgrounding phase, no interaction effects were detected for the variables analyzed. As computed, cost of gain includes all feed and non-feed costs associated with the enterprise. Costs of gain during backgrounding were not statistically different among cow-calf systems or backgrounding systems (Table 5). Although feed costs averaged $\$ 34$ higher for backgrounding in Montana (MT2 and MT3), trucking expenses for calves shipped to Oklahoma (OK1, averaging $\$ 28 / \mathrm{hd}$ ) offset this advantage.

Gross margin per steer reflects market values of steers at the beginning of the feeding period, costs of gain, and market values at the end of the feeding period. No differences were detected among backgrounding systems for gross margin per steer;

\section{Table 4. Economic performance of cow-calf enterprises}

\begin{tabular}{lcc} 
Item & Gross margin per cow, \$ & Ranch gross margin, \$ \\
\hline Calving season ${ }^{1}$ & & \\
LW240 & $128^{\mathrm{ab}}$ & 56,134 \\
LW190 & $108^{\mathrm{ab}}$ & 57,478 \\
ES240 & $107^{\mathrm{ab}}$ & 53,761 \\
ES190 & $89^{\mathrm{b}}$ & 46,499 \\
LS190 & $174^{\mathrm{a}}$ & 81,254 \\
LS140 & $154^{\mathrm{ab}}$ & 75,982 \\
SEM & 16.8 & 8,553 \\
Heifer development & & \\
Constant gain (CG) & 121 & 59,640 \\
Delayed gain (DG) & 132 & 64,063 \\
SEM & 9.7 & 4,938 \\
\hline
\end{tabular}

a,b Least squares means within a column and category with different superscripts are different $(P<0.05)$.

${ }^{1} \mathrm{LW}=$ late winter, ES = early spring, LS = late spring; 240, 190, 140 = weaning ages. 
Table 5. Economic performance of backgrounding enterprises ${ }^{1}$

\begin{tabular}{lcccrcr} 
Item & Cost of gain, \$/kg & SE & Gross margin per steer, \$ & SE & Cumulative gross margin, \$ & SE \\
\hline Cow-calf system & & & & & & \\
LW240 & 1.20 & 0.051 & $-38^{\mathrm{c}}$ & 9.9 & $49,020^{\mathrm{b}}$ & 6,881 \\
LW190 & 0.99 & 0.051 & $-12^{\mathrm{bc}}$ & 9.9 & $51,382^{\mathrm{ab}}$ & 6,881 \\
ES240 & 1.14 & 0.054 & $-6^{\mathrm{abc}}$ & 10.5 & $53,585^{\mathrm{b}}$ & 7,339 \\
ES190 & 1.05 & 0.051 & $16^{\mathrm{ab}}$ & 9.9 & $47,314^{\mathrm{b}}$ & 6,881 \\
LS190 & 1.10 & 0.054 & $5^{\mathrm{abc}}$ & 10.5 & $81,039^{\mathrm{a}}$ & 7,339 \\
LS140 & 1.02 & 0.051 & $34^{\mathrm{a}}$ & 9.9 & $80,321^{\mathrm{a}}$ & 6,881 \\
Background & & & & & \\
system & 1.13 & 0.039 & 9 & 7.5 & 63,174 & 5,218 \\
OK1 & 1.04 & 0.036 & -10 & 7.0 & 57,897 & 4,866 \\
MT2 & 1.08 & 0.036 & 1 & 7.0 & 60,260 & 4,866 \\
MT3 & & & & & \\
\hline
\end{tabular}

a-cLeast squares means within a column and category with different superscripts are different $(P<0.05)$.

${ }^{1} \mathrm{LW}=$ late winter, $\mathrm{ES}=$ early spring, $\mathrm{LS}=$ late spring; $240,190,140=$ weaning ages; OK1 = backgrounded and finished in

Oklahoma; MT2 = backgrounded in Montana, finished in Oklahoma; MT3 = backgrounded and finished in Montana.

however, cow-calf systems were different (Table 5). Gross margin per steer was highest for LS140 and lowest for LW240 and LW190 $(P<0.05)$. Other systems were intermediate and not different from one another. These results suggest that under the conditions of this study, steers that were lighter entering backgrounding (i.e., ES190, LS190, LS140) were more profitable than heavier steers (i.e., LW240, LW190, ES240) even though total gains for these groups were not different within location (Grings et al., 2006, Phillips et al., 2006).

Due to differences in herd sizes sustainable on a fixed range resource (Table 1), numbers of steers fed differed among cow-calf systems. Average numbers of steers weaned for LW240, LW190, ES240, ES190, LS190, and LS140 were 176, 213, 207, 219, 194, and 207, respectively. Differences in cumulative gross margins for these systems after backgrounding reflect differences in ranch gross margin plus differences in gross margin per steer and numbers of steers fed. Cumulative gross margin after backgrounding was greatest for LS190 and LS140 and lowest for LW240 and ES190 ( $P$ $<0.05$, Table 5). Values for LW190 and ES240 were intermediate and not different from other systems. Dif- ferences in cumulative gross margin among backgrounding systems were not significant, consistent with the results for cost of gain and gross margin per steer.

\section{Finishing Systems}

During the finishing phase, differences in cost of gain were detected among cow-calf systems and backgrounding systems, but not between finishing systems (Table 6). More important, cow-calf system $\times$ background system interaction effects were significant $(P<0.05)$. Figure 1 shows that costs of gain for calves backgrounded in Montana and finished in Oklahoma (MT2) were much higher than for calves backgrounded in other systems. These differences reflect the high costs of transporting backgrounded steers from Montana to Oklahoma (averaging $\$ 44 / \mathrm{hd}$ for MT2), which were greatest for older and heavier steers (within MT2 averaging $\$ 51, \$ 43$, and $\$ 38 / \mathrm{hd}$ for LW, ES, and LS, respectively). Note that for the finishing phase, only MT2 incurred transportation costs to the finishing location. Within MT2, costs of gain were greatest for steers from LW and lowest for steers from LS with ES intermediate; all these comparisons were significant $(P<$ 0.05). However, ES240 was not dif- ferent from LS140 or LS190. Within MT2, differences in costs of gain between weaning times within calving seasons were not significant, although costs of gain for early weaned steers tended to be greater than for late weaned steers. No differences between and within OK1 and MT3 were significant.

During finishing, differences in gross margin per steer were detected among backgrounding systems but not cow-calf or finishing systems (Table 6). Interaction effects were not detected. All least squares means were negative. Losses were greatest for MT2 and lowest for MT3 reflecting the high cost of transportation for steers in MT2 and lower feed costs for MT3.

Because gross margins per steer during the finishing phase were all negative, cumulative gross margins after finishing were all lower than after backgrounding (Tables 5 and 6). Cumulative gross margins for LS140 and LS190 were greater than for all other systems $(P<0.05)$, which were similar. Rankings for backgrounding systems followed the pattern seen for gross margin per steer. Interaction effects for cumulative gross margin were not significant.

Our objective was to evaluate LW, $\mathrm{ES}$, and LS calving in combination with backgrounding and finishing 
Table 6. Economic performance of finishing enterprises ${ }^{1}$

\begin{tabular}{|c|c|c|c|c|c|c|}
\hline Item & Cost of gain, $\$ / \mathrm{kg}$ & SE & Gross margin per steer, \$ & SE & Cumulative gross margin, $\$$ & SE \\
\hline \multicolumn{7}{|c|}{ Cow-calf system² } \\
\hline LW240 & $1.96^{\mathrm{ab}}$ & 0.083 & -136 & 11.9 & $26,490^{\mathrm{b}}$ & 5,279 \\
\hline LW190 & $2.14^{\mathrm{a}}$ & 0.083 & -137 & 11.9 & $22,024^{b}$ & 5,279 \\
\hline ES240 & $1.55^{c}$ & 0.088 & -139 & 12.8 & $26,201^{b}$ & 5,670 \\
\hline ES190 & $1.67^{\mathrm{bc}}$ & 0.083 & -152 & 11.9 & $13,659^{b}$ & 5,279 \\
\hline LS190 & $1.36^{c}$ & 0.088 & -122 & 12.8 & $58,159^{a}$ & 5,670 \\
\hline LS140 & $1.44^{\mathrm{c}}$ & 0.083 & -139 & 11.9 & $51,367^{a}$ & 5,279 \\
\hline \multicolumn{7}{|c|}{ Background system } \\
\hline OK1 & $1.39^{b}$ & 0.055 & $-132^{a}$ & 8.1 & $36,996^{a}$ & 3,587 \\
\hline MT2 & $2.41^{a}$ & 0.050 & $-184^{b}$ & 7.5 & $20,987^{b}$ & 3,336 \\
\hline MT3 & $1.26^{b}$ & 0.080 & $-96^{c}$ & 12.0 & $40,968^{a}$ & 5,306 \\
\hline \multicolumn{7}{|l|}{ Finish system } \\
\hline Confinement & 1.69 & 0.042 & -133 & 6.3 & 33,958 & 2,785 \\
\hline Pasture & 1.68 & 0.059 & -142 & 8.9 & 32,009 & 3,951 \\
\hline
\end{tabular}

${ }^{a-c}$ Least squares means within a column and category with different superscripts are different $(P<0.05)$.

${ }^{1} \mathrm{LW}=$ late winter, $\mathrm{ES}=$ early spring, LS = late spring; 240, 190, 140 = weaning ages; OK1 = backgrounded and finished in Oklahoma, MT2 = backgrounded in Montana, finished in Oklahoma, MT3 = backgrounded and finished in Montana.

${ }^{2}$ Note that the cow-calf $\times$ background interaction was significant for cost of gain. See Figure 1.

steer calves in Montana or Oklahoma. All systems were modeled to be consistent with the experimental factors of a comprehensive, multiregional study for which animal performance has been previously reported (Grings et al., 2005, 2006,

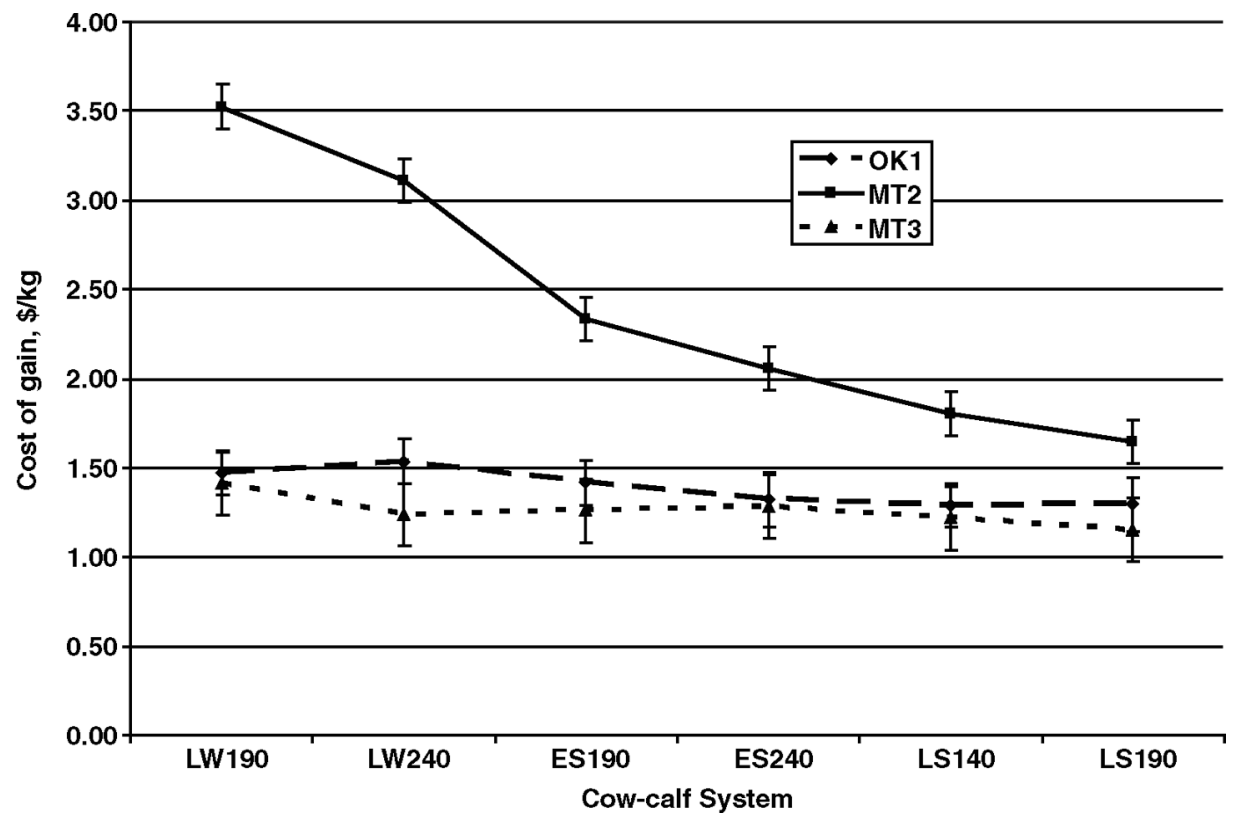

Figure 1. Cow-calf system $\times$ background system interaction for cost of gain $(\$ / \mathrm{kg} \pm \mathrm{SE})$ during the finishing phase. Cow-calf systems: LW = late winter, ES = early spring, LS = late spring; 240, 190, 140 = weaning ages. Background systems: OK1 = backgrounded and finished in Oklahoma; MT2 = backgrounded in Montana, finished in Oklahoma; MT3 = backgrounded and finished in Montana.
2007; Phillips et al., 2006). Central to our approach was our use of all performance data available from the study as well as all available information on production inputs. Because all production inputs were not measured (e.g., grazed forage), com- puter simulation was used to predict inputs that were not measured. The arrangement of factors evaluated in this study (calving time, weaning age, heifer development, backgrounding strategy, and finishing method) allows inferences to several, but not all possible combinations of these factors. As is the case with any modeling study, the results are sensitive to the assumptions employed. A key assumption in this study was that the most limiting resource to the cow-calf enterprise was land (i.e., grazeable forage).

Late spring or summer calving has been proposed as an effective way to lower cow feed costs, by better matching nutrient requirements to available nutrients from grazed forage and by extending the grazing season (Adams et al., 1996). In the Nebraska Sandhills, Adams et al. (1994) found that management systems that utilized more grazed forage during the winter and during the breeding season, and especially higher quality sub-irrigated meadows, had lower annual cow feed costs (\$/cow) than systems that utilized more hay or lower quality pasture. In a related study, Stockton et al. (2007) found that compared with 
March calving, production costs for cows calving in June were lower and net returns higher. Differences in net return were larger when calves were sold at weaning than if calves were fed to harvest weight. May et al. (1999b), utilizing mixed integer programming models, concluded that calving in June vs. February reduced cow feed costs by allowing cows to graze native range or domestic forages for a longer period, reducing the amount of hay fed per cow. Julien and Tess (2002) also demonstrated an economic benefit to lengthening the grazing season, although over a relatively restricted range of days. Using computer simulation, Reisenauer Leesburg et al. (2007a) concluded that in beef enterprises in the Northern Great Plains that were constrained to a limited grazing season with limited access to low-cost high quality winter forage, switching from early spring to summer or fall calving date was not expected to improve profitability. In this study, when calves were marketed at weaning, differences in gross margin favored LS calving over LW or ES, largely due to savings in cow feed costs. Advantages associated with LS calving were largely retained through backgrounding and finishing.

Few studies of calving seasons have evaluated the entire enterprise, but have focused on feed costs (Adams et al., 1996; May et al., 1999b). Pang et al. (1999) studied a complete enterprise but assumed no constraints on feed resources and calculated profit on a per cow basis. These approaches cannot account for differences in herd size required by switching calving seasons (i.e., profit per cow and profit per ranch do not necessarily rank systems the same when herd size is different) and ignore some very real constraints faced by ranchers. Similar to Reisenauer Leesburg et al. (2007a,b), in this study ranch size was constrained in an attempt to better represent the net effect of changing calving dates on a ranch enterprise.

This study looked specifically at changing calving date without changes in grazing strategy or calf marketing, as well as in combination with retained ownership through backgrounding or finishing, or both. In anecdotal reports about changing calving seasons, most ranches studied have also implemented several management and marketing changes when calving seasons were changed (e.g., May et al., 1999a). Hence, the effects of changing calving dates were confounded with changes in grazing management and marketing of calves. Pang et al. (1999) simulated spring vs. fall calving with several weaning ages and found that for weaning ages of less than $200 \mathrm{~d}$, spring calving was more efficient than fall calving (net returns per cow per year), but fall calving was more efficient at older weaning ages. Reisenauer Leesburg et al. (2007b) evaluated early spring, late spring, and fall calving in combination with backgrounding or finishing in confinement systems at 4 different stages of the cattle cycle. They concluded that no one combination of calving season, backgrounding, and finishing was superior throughout the cattle cycle.

Retained ownership should be regarded as a separate enterprise from the cow-calf production enterprise. For cow-calf managers dependent on custom feedlots to retain ownership of their calves, the decision to retain ownership can be a new decision every year. McKissick and Ikerd (2002) referred to retained ownership decisions as "short run" when compared with cow-calf decisions. It should be emphasized that profitability of any retained ownership enterprise is dependent on several factors that can vary greatly across specific sets of circumstances, including market values of weaned calves, feed costs, transportation costs, health costs, mortality, and sale prices. Quality factors associated with producers, genetics, and health management (source, genetic, and process verification) can also bring market discounts or premiums. Additional decision factors not considered in this study include cash flow, financing, and income taxes. White et al. (2007) reviewed many of these factors and concluded that the decision to retain ownership of calves past weaning should be based on an understanding of beef industry structure, accounting for estimable risks and the risk tolerance. Recent changes in the beef industry serve to highlight the importance of these factors. Rising fuel and feed prices are motivating producers to re-evaluate their production and marketing practices. Input and output prices used in this study were based on the years when the live-animal portion of the study was conducted. Using current prices for trucking, feed and pasture could easily change the ranks of the systems studied.

\section{IMPLICATIONS}

Many cow-calf producers consider changes in calving season either to increase fall calf weights or to more closely match nutrient requirements to the available forage quality. For producers in the Northern Great Plains with resources similar to those available in this study, late spring calving offers promise as a means to increase profit. Several variables should be considered in the decision to retain ownership of steer calves past weaning, especially the value of calves at weaning, expected costs of gain, and expected market prices at the end of the feeding period. Transportation and feed costs are critical variables affecting the costs of gain in retained ownership enterprises.

\section{LITERATURE CITED}

Adams, D. C., R. C. Clark, S. A. Coady, J. B. Lamb, and M. K. Nielsen. 1994. Extended grazing systems for improving economic returns from Nebraska Sandhills cow/calf operations. J. Range Manage. 47:258.

Adams, D. C., R. C. Clark, T. J. Klopfenstein, and J. D. Volesky. 1996. Matching the cow with the forage resources. Rangelands 18:57.

Adams, D. C., R. C. Clark, R. Sandberg, G. Carriker, T. Klopfenstein, and T. Milton. 2001. June versus March calving for the $\mathrm{Ne}$ - 
braska sandhills: Production traits. p. 8 in 2001 Nebraska Beef Report. Univ. Nebraska Cooperative Extension MP 76-A.

Armstrong, S. L., J. W. Wilton, W. C. Pfeiffer, and L. R. Schaeffer. 1990. Influence of variations in biological and economical parameters on beef production net returns. J. Anim. Sci. 68:1857.

Grings, E. E., T. W. Geary, R. E. Short, and M. D. MacNeil. 2007. Beef heifer development within three calving systems. J. Anim. Sci. 85:2048.

Grings, E. E., W. A. Phillips, R. E. Short, H. Mayeux, and R. K. Heitschmidt. 2006. Postweaning performance of steers from varying calving and weaning strategies in Montana. Prof. Anim. Sci. 22:386.

Grings, E. E., R. E. Short, K. D. Klement, T. W. Geary, M. D. MacNeil, M. R. Haferkamp, and R. K. Heitschmidt. 2005. Calving system and weaning age effects on cow and preweaning calf performance in the Northern Great Plains. J. Anim. Sci. 83:2671.

Julien, D. J., and M. W. Tess. 2002. Effects of breeding date, weaning date, and grazing season length on profitability of cow-calf production systems in southeastern Montana. J. Anim. Sci. 80:1462.

May, G. J., L. W. Van Tassell, M. A. Smith, and J. W. Waggoner. 1999a. Delayed calving in Wyoming. Rangelands 21:8.
May, G. J., L. W. van Tassell, J. W. Waggoner, and M. A. Smith. 1999b. Relative costs and feeding strategies associated with winter/spring calving. J. Range Manage. 52:560.

McKissick, J. C., and J. Ikerd. 2002. Retained Ownership in Cattle Cycles. In Managing for Today's Cattle Market and Beyond. Livestock Marketing Information Center. http://www.lmic.info/memberspublic/ pubframes.html Accessed March 16, 2006.

Pang, H., M. Makarechian, J. A. Basarab, and R. T. Berg. 1999. Application of a dynamic simulation model on the effects of calving season and weaning age on bioeconomic efficiency. Can. J. Anim. Sci. 79:419.

Peterson, G. A., T. B. Turner, K. M. Irvin, M. E. Davis, H. W. Newland, and W. R. Harvey. 1987. Cow and calf performance and economic considerations of early weaning of fall-born beef calves. J. Anim. Sci. 64:15.

Phillips, W. A., E. E. Grings, R. E. Short, R. K. Heitschmidt, S. W. Coleman, and H. S. Mayeux. 2006. Effects of calving season on stocker and feedlot performance. Prof. Anim. Sci. 22:392.

Reisenauer Leesburg, V. L., M. W. Tess, and D. Griffith. 2007a. Evaluation of calving seasons and marketing strategies in Northern Great Plains beef enterprises: I. Cow-calf systems. J. Anim. Sci. 85:2314.
Reisenauer Leesburg, V. L., M. W. Tess, and D. Griffith. 2007b. Evaluation of calving seasons and marketing strategies in Northern Great Plains beef enterprises: II. Retained ownership systems. J. Anim. Sci. 85:2322.

Smith, M. A., J. W. Waggoner, D. M. Perry, R. H. Hart, and G. Younglove. 2001. Late spring calving lowers cow wintering costs with minimal impact to calf performance. Proc. West. Sec. Am. Soc. Anim. Sci. 52:231.

SRM. 1989. Glossary of terms used in range management. 4th ed. Soc. Range Manage., Wheat Ridge, CO.

Stockton, M. C., D. C. Adams, R. K. Wilson, T. J. Klopfenstein, R. T. Clark, and G. L. Carriker. 2007. Production and economic comparisons of two calving dates for beef cows in the Nebraska Sandhills. Prof. Anim. Sci. 23:500.

Tess, M. W., and B. W. Kolstad. 2000a. Simulation of cow-calf production systems in a range environment: I. Model development. J. Anim. Sci. 78:1159.

Tess, M. W., and B. W. Kolstad. 2000b. Simulation of cow-calf production systems in a range environment: II. Model evaluation. J. Anim. Sci. 78:1170.

White, B. J., J. D. Anderson, R. L. Larson, K C. Olson, and D. U. Thomson. 2007. Review: The cow-calf operation retained ownership decision. Prof. Anim. Sci. 23:18. 